\title{
Exploring the emotional intelligence of leaders in governance of non-profit sports organizations: A voluntary vs. non-voluntary comparison
}

\author{
Özlem Özdinç ${ }^{1}$ \\ Pervin Bilir ${ }^{2}$ \\ Yalım Özdinç
}

\begin{abstract}
Research and practice have overlooked the emotional intelligence (EI) of senior leaders in nonprofit organizations. Our research aims to explore and compare the EI capacity of two groups of such leaders; voluntary (i.e., presidents of sport federations) and remunerated (i.e., provincial directors of sports), in the sport governance system of Turkey. The results of a small-scale census revealed that voluntary leaders were older, had more years of sporting experience, and achieved significantly higher EI scores than their paid counterparts. A regression analysis to examine whether age and sporting experience predicted the EI scores returned positive results for age only. A priori and post hoc power analyses assured that results had sufficient power for practically meaningful implications (.95 and .85 , respectively). These results suggest that sports-governing non-profit organizations can benefit from some EI training for the development of their leaders, including those younger and with limited sporting experience. We discuss the implications of our findings within the metamorphosis of sports governing bodies from a non-profit organization to a more business-like entity.
\end{abstract}

Keywords: Sport management; leadership; sport governance; non-profit sports organizations; emotional intelligence.

\section{INTRODUCTION}

People and managing relationships with people are at the core of leadership. Within the non-profit sports organization (NSO) context, where a leader's span of control includes voluntarily hired individuals, leadership is about altruist people who have community-centered motivations (such as using skills to help others) and are enticed into the solidaristic nature of uncoerced works (Khoo and Engelhorn, 2011; Kolar et al., 2016). Therefore, presiding over volunteering workforce is more challenging for leaders who preponderantly are also volunteers, compared to that over salaried workforce for paid leaders (Sport New Zealand, 2015a, p. 6). The human resources line of NSO research has reported this challenge in terms of shrinking supply of volunteering labor (Wicker and Breuer, 2011; Breuer et al., 2012; Shilbury, 2015, p. 109;), and

\footnotetext{
${ }^{1}$ Lecturer (PhD in Physical Education and Sports), Faculty of Arts, Whitireia Community Polytechnic, Auckland, New Zealand, Ozlem.Ozdinc@,whitireia.ac.nz

2 Assoc. Prof. (PhD in Physical Education and Sports), Sports Management Department, School of Physical Education and Sports, Çukurova University, Adana, Turkey, pbilir@cu.edu.tr

${ }^{3}$ Lecturer (PhD in Marketing), Applied Business Studies, Faculty of Business, Whitireia Community Polytechnic, Auckland, New Zealand, Yalim.Ozdinc@,whitireia.ac.nz
} 
Özdinç, Ö., Bilir, P., \& Özdinç, Y. (2017). Exploring the emotional intelligence of leaders in governance of non-profit sports organizations: A voluntary vs. non-voluntary comparison. Journal of Human Sciences, 14(4), 4464-4479. doi:10.14687/jhs.v14i4.4839

escalating turnover rates for long-term official (Chelladurai, 2006) and leadership volunteers (Wicker and Breuer, 2013). The same line of studies has also shown that commitment terminations at NSOs are mostly due to volunteer dissatisfaction and lack of both encouragement and recognition of voluntary labor (Bussell and Forbes, 2002; Breuer et al., 2012). Among senior leaders in NSOs, weak orientation towards collective solidarity and poor recognition are reportedly the major causes of quitting voluntary leadership positions (Schlesinger et al., 2013). In summary, the human resources stream of NSO research indicates that the management of human capital is weak in NSOs.

Retaining human capital in NSO settings depends highly on the nourishment of the volunteer's emotional and social ties to the NSO and its members (Engelberg et al., 2012; Schlesinger et al., 2013). Leadership research in both for-profit non-sport (Goleman, 1995; 1998; George, 2000; Wong and Law, 2002) and non-profit sports settings (Schneider, 2012; Magnusen and Perrewé, 2016) suggests that maintaining a work environment that stimulates emotional and social ties is more likely when emotionally intelligent leaders are in charge. Accordingly, in countries where the sporting system is largely or entirely governed by NSOs, such as New Zealand and Australia, emotional intelligence (EI) is a sought-after quality for senior leadership positions (Sport New Zealand, 2015b, p. 19). However, our knowledge of EI in NSO leadership is mostly based on inferences from research with camp leaders (Magyar et al., 2007), team captains (Stough et al., 2009; Voight, 2014) and coaches (Thelwell et al., 2008; Chan and Mallett, 2011; Hwang et al., 2013). It seems therefore that the EI stream of leadership research in business and sports domains had different focus during their emergence. The former mostly adopted a top-down look by examining the EI of leaders at senior levels (e.g., Daniel Goleman's studies with executives in the 1990s) whereas the latter has favoured a bottom-up look by focusing on the EI of leaders at low-to-middle levels (e.g., coaches). A look at the qualities of volunteering leaders taking up roles at board membership, executive or president levels through an EI lens has mostly been overlooked in the NSO context.

It is, therefore, timely to attempt to fill this void as NSOs have been undergoing an organizational metamorphosis to become more professionally governed bodies by benchmarking against their commercial counterparts (Vos et al., 2012; Maier et al., 2016). However, the motivation for this organizational change is predominantly the need to resolve the NSO's endemic working capital problem (Singer and Yankey, 1991; Lasby and Sperling, 2007; Wicker, Breuer and Hennings, 2012; Cordery et al., 2013; Lu, 2016). A basic understanding of EI as a desirable quality for leadership at the higher levels of NSO governance could grab attention to other metamorphous dimensions, for instance, retaining human capital or leadership training. Such basic understanding could also provide directions for future research in the emerging field of EI in NSO context.

From an EI perspective, we therefore set ourselves a challenge to respond to the calls for examining leadership qualities necessary for a volunteer to lead other volunteers (Brewis et al., 2010) within sport governance systems (Chelladurai, 2006; Hoye, 2006; 2007; Shilbury and Ferkins, 2011; Schlesinger et al., 2013). We conducted a small-scale census to explore the EI of two groups of sports leaders in a Mediterranean country, Turkey. Those leaders were the voluntary presidents of sport federations and remunerated provincial directors of youth services and sports. Both groups of leaders perform under and in coordination with the Ministry. We made between-groups comparisons of EI scores and examined whether key demographic variables that are time-dependent covariates (age and sporting experience in years) predict the EI of leaders.

The following sections present the theoretical background to our study, starting with a brief overview of the emergence of the EI concept. In three sub-sections, we then provide short reviews of EI research in sports, the constructs developed to measure EI and those widely used in sports sciences, respectively. Later, the sport governance system in the study location is 
Özdinç, Ö., Bilir, P., \& Özdinç, Y. (2017). Exploring the emotional intelligence of leaders in governance of non-profit sports organizations: A voluntary vs. non-voluntary comparison. Journal of Human Sciences, 14(4), 4464-4479. doi:10.14687/jhs.v14i4.4839

outlined. Methodological details, findings, and a discussion of the results follow. A section on implications for practice and research concludes the paper.

\section{THEORETICAL BACKGROUND}

The idea of multi-dimensional intelligence dates back to 1909 when the social intelligence concept was introduced as a set of abilities complementing cognitive skills (Landy, 2006). The attempt to conceptualize alternative components of intelligence did not come until 1986 when Gardner developed the multiple intelligence theory (MIT) (Gardner, 2011). The MIT suggests six dimensions for abilities; those are, linguistic, musical, logical-mathematical, spatial, bodilykinesthetic, and personal intelligence. The concept of EI emerged from the 'personal intelligence' aspect in Gardner's MIT, which captures both intrapersonal (i.e., the capacity to understand selfdesires and feelings) and interpersonal intelligence (i.e., one's ability to understand others' motivations and emotions).

\section{EI in Sports Settings}

Sport influences the emotions and moods of individuals and crowds due to its festive and competitive nature. Although closely related, the terms emotion and mood are semantically different (Ekkekakis, 2013). Emotions are episodic internal events that coordinate a complex set of psychological subsystems interrelated with one's changing relationships with people, things, or events (Mayer et al., 1999, p. 267), such as envy, love, and hate. Moods, compared to emotions, last longer and are not explicit; but diffuse and global, such as vigor and fatigue (Ekkekakis, 2013, p. 43). These terms have been studied in the sport psychology (e.g., Johnson, 1949; Simmons, 1959) and sociology domains (e.g., Firth, 1930; Beaglehole, 1937) long before EI was coined.

Following the conceptualization of EI, its first applications in the 1990s were, however, not in the emotion-laden sports or NSO domains, but mostly in for-profit organizations where emotions were historically forborne from valuing. This line of management research initially measured the EI of individuals taking up leadership positions at executive levels. Conversely, EI research in sports that emerged as an area of inquiry in the 2000s has mainly studied people in non-executive roles. The first direct attribute to EI in sport domain appears in McCann's paper, which-although briefly-expresses the importance of EI for elite athletes (McCann, 1999). From then on, studies in sport psychology have shown that EI affects athletes' mood state (Laborde et al., 2011; Lane and Wilson, 2011), mental strength (Lane, Thelwell et al., 2009), and sporting performance (Zizzi and Deaner, 2003; Lane et al., 2009; Lane et al., 2010). Sport scientists have examined the influence of perceiving, understanding and utilizing emotions (e.g., managing stress) on sporting success (Botterill and Brown, 2002; Lozovina et al., 2012) in various sports. Among examples are basketball (Stough et al., 2009), mountaineering (Castanier et al., 2011), and ocean sailing (Puig and Villanova, 2011). Other studies have looked at how the EI ability influences team capacity (Crombie et al., 2009) and coaching effectiveness (Thelwell et al., 2008; Chan and Mallett, 2011). Additionally, a line of sport physiology research has shown that EI can improve the physical performance of not just sedentary individuals (Costarelli and Stamou, 2009) but also athletes of indoor and outdoor sports (Bal et al., 2011).

The indication of this body of literature is that the emotion aspect of sports highlights some necessary athletic qualities that the umbrella term EI contains. However, emotions, as studied by sport scientists, are not entirely the same as those EI captures. It seems that studies in sport psychology and physiology have mostly considered EI as an intrapersonal intelligence (as in Gardner's MIT), and overlooked that it is also an interpersonal ability to understand and manage others' emotions. This implies that the focus of EI research in business and sport domains has been different. While EI in business contexts considered the concept as an interpersonal ability and examined it initially on executives, EI in sports considered the concept more of an 
Özdinç, Ö., Bilir, P., \& Özdinç, Y. (2017). Exploring the emotional intelligence of leaders in governance of non-profit sports organizations: A voluntary vs. non-voluntary comparison. Journal of Human Sciences, 14(4), 4464-4479. doi:10.14687/jhs.v14i4.4839

intrapersonal ability and favored a bottom-up look by examining the concept mostly among line and middle-level sportsmen (such as athletes and coaches).

\section{The Conceptions and Measurement of EI}

Three main streams of EI research have offered the ability, mixed, and trait models of the concept, each proposing measures to quantify EI. Introduced by Salovey and Mayer (1990), the ability model is based on information processing. They first developed the Multifactor Emotional Intelligence Scale (MEIS), a 402-item device composed of four branches that assesses one's ability in perceiving, utilizing, understanding, and managing emotions (Mayer et al., 1999, pp. 273278). Because the MEIS was based on IQ tests, responses to its items were either correct or incorrect. To determine a correct answer, scores in each branch were attuned to social norms through a triangulation that involves a between-groups comparison of consensus scores, expert identification, and target's assessment (p. 280). The MEIS was later improved as Mayer-SaloveyCaruso Emotional Intelligence Test (MSCEIT), a 141-item construct including the same four branches. Different than its predecessor, the MSCEIT yields seven scores; four of which are individual branch scores, one experiential EI score, one strategic EI score (the combined scores of the first and last two branches, respectively), and a total EI score (Brackett and Salovey, 2006).

Goleman, who suggests that people are born with a general EI but not emotional competency, introduced the mixed model of EI. According to this model, one must work to master their emotional capabilities. Goleman's framework offers a five-component EI model, including the self-awareness, self-regulation, motivation, empathy, and social skill dimensions (Goleman, 1998). Mixed model constructs are self-report designs measuring competencies rather than intelligence. The first such device was the Emotional Competency Inventory (ECI) developed by Boyatzis et al. (1999), which was later improved to form ECI-2.0. The ECI-2.0 is a quadripartite model (self-awareness, self-management, social awareness, and relationship management) that measures 18 competencies in total (Wolff, 2005, p. 2).

Petrides and Furnham (2000) suggested the trait EI model (also known as emotional selfefficacy) that refers to one's self-perception of their emotional abilities. They argued that ability EI devices measure actual emotion-related cognitive abilities by a performance test, whereas selfreport EI constructs measure self-perceived emotion-related abilities and traits (Petrides and Furnham, 2006, p. 554). Their argument reflects the authors' view of EI that it relates more to behavioural consistency in different situations (e.g., manifests in particular traits or behaviours such as empathy and assertiveness) than to information-processing abilities (such as perceiving and utilising emotions) (Petrides and Furnham, 2000, p. 314). In sum, the conceptual difference between the trait and ability models is in the measurement of EI. The 33-item Self-report EI Scale (SREIS) developed by Schutte et al. (1998) is an example of the self-report measures that map onto ability tests.

\section{Constructs Used to Measure EI in Sport Sciences}

In sport psychology, the use of performance tests (such as the MSCEIT) has been limited due to their less practicality (Meyer and Fletcher, 2007). EI studies in the sport domain have mainly favored self-report ability tests based on traits. Other than the ECI, researchers have used Bar-On's Emotional Quotient Inventory (Bar-On EQ-i) (e.g., Costarelli and Stamou, 2009; Lu et al., 2010) and the Trait EI Questionnaire (e.g., Laborde et al., 2011; Laborde, Dosseville et al., 2014; Laborde, Lautenbach et al., 2014). Another line of EI research in sports has employed compact self-report scales that map onto ability tests. This stream of studies validated the use of SREIS in sports (Lane, Meyer et al., 2009), and has widely employed this scale in the areas of sport psychology (e.g., Lane et al., 2010; Solanki and Lane, 2010; Lane and Wilson, 2011; Hwang et al., 2013). A review of the EI studies in sports that use the SREIS has reported that the compact construct is reliable (Meyer and Zizzi, 2007). 
Özdinç, Ö., Bilir, P., \& Özdinç, Y. (2017). Exploring the emotional intelligence of leaders in governance of non-profit sports organizations: A voluntary vs. non-voluntary comparison. Journal of Human Sciences, 14(4), 4464-4479. doi:10.14687/jhs.v14i4.4839

\section{The Governance of Sports in Study Location: An Overview}

A Ministry, dedicated to sports, administers sporting events in Turkey. Through its heteronomous and supervised autonomous units, the Ministry governs youth services, amateur and professional sporting events at regional, national and international levels, and legal sports betting and pari-mutuels (Ministry, 2014).

The ministerial unit that implements the governance of youth services and sports in cities is the provincial directorate. Organizing sporting camps and sports competitions in school leagues, for example, are among the responsibilities of the local directorate. Provincial directors report to the General Director, who performs under the Minister. According to the relevant Act, the General Director makes assignments to the provincial director position, which is a tenured and remunerated government post.

The supervised autonomous units that implement the governance of sports at amateur and professional levels are sport federations. Similar to their French counterparts, sport federations in the study destination function under the close supervision of the Ministry. They gained a partial autonomy from the government in 2004 when the parliament passed an amendment to the Act. The change introduced an election-based independent management system, replacing the assignment-based fulfillment of the president position by the General Director. However, it kept the General Director as the superintendent of federations' budget (Erturan-Ogut and Sahin, 2014). This legal status of federations compares to the Spanish system where Spanish Ministry of Education, Culture, and Sport authorizes and approves by the statutes and budgets of sport federations (Spanish Ministry of Education, Culture, and Sport, 2014). The president position at sport federations is a voluntarily assumed duty in the country where the study was carried out.

\section{METHODOLOGY}

We collected data from the presidents of sport federations and the provincial directors of sports. The census of presidents (62) and provincial directors (81), as of mid-2016, constituted a relatively small population $(\mathrm{N}=143)$. Accordingly, a census survey was aimed. The possibility of a low response rate necessitated power analysis to determine size requirements for the design. Through a pilot study, we sought the optimization of the minimum effect that would practically be meaningful for the possible implications of the study.

\section{Instrument and Procedures}

We used the SREIS on a 5-point scale ( $1=$ strongly disagree) to measure EI scores. Gender, age, and sporting experience were the three demographic variables on the instrument. A dichotomous question asked respondents whether they would like to receive an executive summary of the results.

Three bilingual experts translated the SREIS from English to the target language through a process of forward-back translations. Experts were native speakers of the target language, had excellent knowledge of English, and achieved quality-assured international publications in their fields. A language expert performed provisional forward-translation, and another language expert did back-translation. The third, who was a researcher in psychology, independently checked translator interpretations for conceptual fit. The negotiated final translation underwent a local testing at the institution of the second author, with a conveniently selected small group comprising three academic and three administrative staff members, and three postgraduate students. Feedback from the test subjects assured appropriate wording in target language.

Following a pilot study, we sent the leaders email invitations to the online survey. By appointment, we visited a handful of federation presidents and provincial directors, who were geographically accessible for data collection. Overall, data collection lasted for nearly seven 
Özdinç, Ö., Bilir, P., \& Özdinç, Y. (2017). Exploring the emotional intelligence of leaders in governance of non-profit sports organizations: A voluntary vs. non-voluntary comparison. Journal of Human Sciences, 14(4), 4464-4479. doi:10.14687/jhs.v14i4.4839

months, as we had to make multiple reminders for participation in the online survey to maintain a sufficient response rate.

\section{Pilot Study}

We first employed the SREIS on a conveniently selected group $(n=26)$ to determine the observation amount needed and power for the study. The pilot group consisted of two provincial directors and 24 members of a sport federation. The federation members included 10 board members, six referees, five coaches, two club managers, and a president. All subjects were male. They ranged in age from 31 to $63(M=47.9, S D=8.2)$, in sporting experience from four to 30 years $(M=13.8, S D=8.3)$, and scored on average $M=3.9(S D=.6)$ on the SREIS, ranging from 2.9 to 4.5 . The EI scores were significantly correlated with age, $r(24)=.581, p<.01$; but not with sporting experience, $r(24)=.218, p=.29$.

Based on these statistics, the non-central probability for $\alpha=.05$ found critical $R^{2}=.187$, and that 32 observations would produce the power of .95 (see Appendix A1) to detect a possible linear multiple regression with two predictors (i.e., age and experience; we excluded gender due to the likelihood of male dominance). We sought this size estimation per group for a betweengroups design that would attempt a comparison of the EI scores.

One-week test-retest reliability assessment of the SREIS with the pilot group returned intra-class correlation coefficient .74 with $95 \%$ confidence intervals $(.41, .88), p<.01$. Items were shuffled in the retest round to avoid inflated reliability estimates due to subject's familiarity with the instrument. The average variation in the SREIS scores between two trials was $.11 \pm .27$. Trials showed no difference $(F(1,22)=3.90, p>.06)$ and the SREIS construct was found reliable. Three of the 26 test subjects did not participate in the retest.

\section{Participants and Data Analysis}

The minimum size estimation per group was met as of the 143 invited sport leaders, 87 (38 federation presidents, 49 provincial directors) took part in the study (response rate $=61 \%$ ). The indication of the pilot study that leaders in president and director roles were male-dominant held true. Only two participating leaders $(2 \%)$ were women, both were sport federation presidents. On average, leaders were $M=48.4$ years old $(S D=7.6$, min. 35, max. 65), and ranged in sporting experience from two to 51 years $(M=13.2, S D=10.5)$. They scored $M=3.9(S D=$ .3) on the SREIS, ranging from 3.1 to 4.5 .

We used the Kolmogorov-Smirnov (KS) test and the Q-Q plot to check normality assumptions for the index SREIS scores. A series of $t$-tests examined the EI score difference between the voluntary presidents and the remunerated directors. A regression analysis tested whether age and sporting experience predicted EI.

\section{RESULTS}

The EI scores were normally distributed $(K S(87)=.064, p=.196$, see Appendix B). Federation presidents and provincial directors differed significantly in their age and sporting experience. On average, the former group of leaders was 4.4 years older and had nearly 12 more years of sporting experience than those comprising the latter group (see table 1). These differences represented a medium-size effect ( $r=.30$ and .32 , respectively). Similarly, the EI of federation presidents ranked significantly higher than that of the provincial directors; however, the effect size of this difference was small $(r=.16)$. 
Özdinç, Ö., Bilir, P., \& Özdinç, Y. (2017). Exploring the emotional intelligence of leaders in governance of non-profit sports organizations: A voluntary vs. non-voluntary comparison. Journal of Human Sciences, 14(4), 4464-4479. doi:10.14687/jhs.v14i4.4839

Table 1 Age, Sporting Experience and EI Comparisons among Sport Leaders

\begin{tabular}{|c|c|c|c|}
\hline & Federation presidents ${ }^{a}$ & Provincial directors & \\
\hline & $M(S D)$ & $M(S D)$ & $t(d f)$ \\
\hline Age & $50.9(7.9)$ & $46.5(6.9)$ & $2.78(85)^{*}$ \\
\hline Sporting experience & $19.7(11.8)$ & $8.1(5.4)$ & $5.62(49.18)^{* *}$ \\
\hline EI & $4.02(.3)$ & $3.87(.3)$ & $2.26(85)^{*}$ \\
\hline
\end{tabular}

\section{Relations of Leader Position, Age, and Sporting Experience to EI}

A leader's position (voluntary president vs. remunerated director) was significantly negatively related to their EI, age, and years of sporting experience with Pearson correlation coefficients $r s=-.24,-.29$ and -.55 , respectively ( $p$ s $<.02$, one-tailed) (see table 2). Age was significantly correlated with the EI score $(r=.36, p<.01)$, however sporting experience was not $(r=.18, p>.06)$. Partial correlation between age and EI was also significant $(r=.31, p<.01)$, and it did not diminish considerably when the effect of position was controlled. We further computed the point-biserial $(\mathrm{pb})$ correlation coefficients to compare independent $r$ s between the age and EI of federation presidents $\left(r_{\mathrm{pb}}=.509, p<.01\right.$, one-tailed, $\left.\mathrm{n}=38\right)$ and provincial directors $\left(r_{\mathrm{pb}}=.160, p<.13\right.$, one-tailed, $\left.\mathrm{n}=49\right)$. Following the standardization process $\left[r_{\mathrm{r}}=1 / 2\right.$

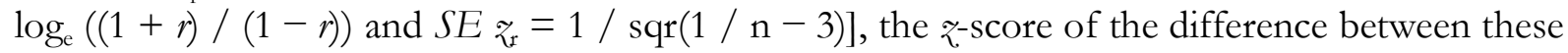
correlations $\left(z_{x 1}-z_{22}\right)$ returned $z_{2}=1.78$, which corresponded to $p=.037$. This suggested that the correlation between age and EI was significantly different in the binary categories of position.

Table 2 Correlation Matrix

\begin{tabular}{lcccc}
\hline & EI & Age & Sporting experience & Position \\
\hline EI & - & $.361^{*}\left[.314^{*}\right]$ & $.182[.063]$ & $-.238^{* *}$ \\
Age & & - & $.353^{*}$ & $-.289^{*}$ \\
Sporting experience & & - & $-.552^{*}$ \\
Position & & & - & - \\
\hline
\end{tabular}

Notes:

Figures in brackets are partial correlation coefficients, controlling for position; remaining figures are zero-order correlation coefficients. Position was coded as $1=$ sport federation president (voluntary leader) and $0=$ provincial director of youth services and sports (remunerated leader). ${ }^{*} p<.01 .{ }^{* *} p<.02$.

Accordingly, we ran a regression analysis to examine whether age and sporting experience predicted EI. We split the file so that position categories could organise the regression output. Age, but not sporting experience, significantly predicted the EI of federation presidents $(\beta=.509, t(36)$ $=3.54, p<.01$ ), accounting for slightly over a quarter of the variance in EI scores $\left(R^{2}=.259\right.$ ) (see table 3). For the provincial directors, neither age nor sporting experience predicted EI. Overall, age significantly predicted a leader's EI $(\beta=.361, t(85)=3.57, p<.01)$.

\section{Post Hoc Power}

We performed power analysis for the regression with two predictors to check whether the effect size in the observed group (overall) was the true population effect. Given the attained size of study group $(\mathrm{n}=87)$, effect size $\left(R^{2}=.130\right)$, and $\alpha(1-\alpha=.436)$, the post hoc power returned .85 , representing a large effect size (Alberson, 2010). Computation details are provided in Appendix A2. 
Özdinç, Ö., Bilir, P., \& Özdinç, Y. (2017). Exploring the emotional intelligence of leaders in governance of non-profit sports organizations: A voluntary vs. non-voluntary comparison. Journal of Human Sciences, 14(4), 4464-4479. doi:10.14687/jhs.v14i4.4839

Table 3 Multiple Regression Results

\begin{tabular}{|c|c|c|c|c|c|c|c|c|c|}
\hline & \multicolumn{3}{|c|}{ Federation presidents ${ }^{a}$} & \multicolumn{3}{|c|}{ Provincial directors $^{\mathrm{b}}$} & \multicolumn{3}{|c|}{ Overall $^{c}$} \\
\hline & $\beta$ & SE $\beta$ & Std. $\beta$ & $\beta$ & SE $\beta$ & Std. $\beta$ & $\beta$ & $S E \beta$ & Std. $\beta$ \\
\hline Step 1 & & & & & & & & & \\
\hline Constant & 3.050 & .277 & & 3.526 & .314 & & 3.320 & .206 & \\
\hline Age & .019 & .005 & $.509^{*}$ & .007 & .007 & .160 & .015 & .004 & $.361^{*}$ \\
\hline Step 2 & & & & & & & & & \\
\hline Constant & 3.048 & .281 & & 3.504 & .316 & & 3.230 & .210 & \\
\hline Age & .019 & .006 & $.499^{*}$ & .009 & .007 & 197 & .014 & .005 & $.339^{*}$ \\
\hline $\begin{array}{l}\text { Sporting } \\
\text { experience }\end{array}$ & .001 & .004 & .041 & -.007 & .009 & -.124 & .002 & .003 & .063 \\
\hline Notes: & & & & & & & & & \\
\hline
\end{tabular}

\section{DISCUSSION}

Our research provides a basic look at the EI capacity of senior leaders in a non-profit sports governance system. We explored and compared the EI of two groups of sport leaders in a Mediterranean country: federation presidents and provincial directors. The members of their branch-specific sport federation elect the former group of leaders who perform voluntarily. The leaders of the latter group are remunerated, and the General Directorate assigns them to their tenured government positions. We entered the participants' age and sporting experience into a regression to test whether these variables predict their EI.

We found that voluntary sport leaders, who scored significantly higher on the SREIS, were older and had more sporting experience than the remunerated leaders. Upon a closer look at this result for a position-based difference, it appeared that EI, age, and sporting experience were positive correlates. This finding was in line with the suggestions of EI research with nonleaders in sports (Kafetsios, 2004; Ruffman et al., 2008; Fernández-Berrocal et al., 2012), as well as that with leaders in for-profit non-sport contexts (Goleman, 1998; Arunima and Ajeya, 2014).

The observed correlation led us to perform a regression analysis to check for the predictability of leaders' EI by their age and sporting experience. The findings of FernándezBerrocal et al. (2012), which suggested EI could change according to one's age, formed our expectation that age could forecast EI scores. The study by Khoo and Engelhorn (2011), which indicated a motivational difference in volunteer commitment by one's expertise in the voluntary sector, was the basis to our anticipation for the sporting experience to predict EI. The test results proved our first expectation correct; that age predicts EI scores, but our similar expectation for sporting experience incorrect. Considering that experience is a time-dependent covariate as age, this result was surprising.

Reading of our findings requires caution, as they must be interpreted within the particular dynamics of the governance system at the study location. While international criticism has expressed the ever-growing centralization and authoritarianism in the country (Kristianasen, 2015), national critiques have reported the influence of political power on ministerial units governing sports (Erturan and Imamoglu, 2011; Sahin and Imamoglu, 2011), through gaps in the relevant Act (Erturan-Ogut and Sahin, 2014). Therefore, our inferences for the senior sport leaders require further investigations of similar governance systems in other geographies before they can be generalized. 
Özdinç, Ö., Bilir, P., \& Özdinç, Y. (2017). Exploring the emotional intelligence of leaders in governance of non-profit sports organizations: A voluntary vs. non-voluntary comparison. Journal of Human Sciences, 14(4), 4464-4479. doi:10.14687/ihs.v14i4.4839

\section{Limitations and Implications}

Research from around the world has implied that women underrepresentation in management positions is typical of not just for-profit (Sandler, 2014) but also NSO settings (Cunningham, 2008; Riot et al., 2008; Wicker, Breuer and von Hanau, 2012; Schlesinger et al., 2013). We observed a similar pattern at out study locale. Women occupying senior positions were few in the sports governance system we surveyed. Consequently, we could not observe differences or relationships involving gender. Future qualitative designs, such as semi-structured interviews with a focus on EI, could provide an insight into the EI traits of female leadership within the context of NSO governance. Alternatively, investigating the topic among sport leaders in female-dominant (such as gymnastics), male-dominant (e.g., wrestling) and unisex sports (such as basketball) for between-groups comparisons could expand our understanding of the relationship between EI and gender among leaders of, for instance, sports clubs. Senior leaders in sports clubs comprise a larger population in most countries in Europe and Americas, which can enable surveys with samples that are larger than the size of the present study's population.

The altruist, motivation-related and solidaristic nature of voluntary labour suggests that NSO leadership demands people-oriented individuals (Harrison and Murray, 2012), who typically prioritise the emotional, social, and cognitive appraisals of the extent to which volunteers' experience meet their primarily visceral expectations (Chelladurai, 2006). Such traits of peopleoriented leaders are conceptualised in the trait theory of EI (Harrison and Murray, 2012, p. 429). Given their need to retain volutary labour NSOs can consider to reap the benefits of leadership training programmes that include sessions on EI. It seems the generally accepted characterisation of a voluntary leader that they have substantial experience (Riot et al., 2008; Schlesinger et al., 2013), as echoed by our results, has a role in the historical underestimation of leadership training in NSOs (Brewis et al., 2010). However, our findings indicate a restricted understanding of EI within NSO setting, which does not suffice to state a bold implication of such training. This is because we neither investigated what sorts of training programmes were in practice at the NSOs nor examined the impact of the EI traits of sport leaders on their effectiveness. Yet, it is likely that some EI training will strengthen the person-orientedness of an NSO leader (Wagstaff et al., 2013), which is necessary to maintain an internal environment that galvanises the emotional and social ties of the voluntary workforce. When trialled in NSOs, the effectiveness of such training programmes can be monitored by 360-degree appraisal designs.

\section{References}

Alberson, C. L., 2010, Applied power analysis for the behavioural sciences. New York: Routledge.

Arunima, S. and J. Ajeya, 2014, "Age and emotional intelligence of healthcare leaders: A study". Advances in Management, 7(7): 41-48.

Bal, B. S., K. Singh, M. Sood and S. Kumar, 2011, "Emotional intelligence and sporting performance: A comparison between open- and closed-skill athletes". Journal of Physical Education and Sport Management, 2(5): 48-52.

Beaglehole, E., 1937, "Emotional release in a Polynesian community". Journal of Abnormal and Social Psychology, 32(3/4): 319-328.

Boyatzis, R. E., D. Goleman and K. Rhee, 1999, "Clustering competence in emotional intelligence: Insights from the Emotional Competence Inventory (ECI)". In Bar-On R and D. A. Parker (eds.), Handbook of emotional intelligence. San Francisco: Jossey Bass, pp. 343-362.

Botterill, C. and M. Brown, 2002, "Emotion and perspective in sport". International Journal of Sport Psychology, 33(1): 38-60.

Brackett, M. A. and P. Salovey, 2006, "Measuring emotional intelligence with the Mayer-SaloveyCaruso Emotional Intelligence Test (MSCEIT)”. Psicothema, 18(Suppl.): 34-41. 
Özdinç, Ö., Bilir, P., \& Özdinç, Y. (2017). Exploring the emotional intelligence of leaders in governance of non-profit sports organizations: A voluntary vs. non-voluntary comparison. Journal of Human Sciences, 14(4), 4464-4479. doi:10.14687/jhs.v14i4.4839

Breuer, C., P. Wicker and T. von Hanau, 2012, "Consequences of the decrease in volunteers among German sports clubs: Is there a substitute for voluntary work?". International Journal of Sport Policy and Politics, 4(2): 173-186.

Brewis, G., M. Hill and D. Stevens, 2010, "Valuing volunteer management skills". Retrieved from http://www.ivr.org.uk/component/ivr/valuing-volunteer-management-skills on 04 May 2017.

Bussell, H. and D. Forbes, 2002, "Understanding the volunteer market: The what, where, who and why of volunteering". International Journal of Nonprofit and Voluntary Sector Marketing, 7(3): 244-257.

Castanier, C., C. Le Scanf and T. Woodman, 2011, "Mountaineering as affect regulation: The moderating role of self-regulation strategies". Anxiety, Stress, \& Coping, 24(1): 75-89.

Chan, T. J. and C. J. Mallett, 2011, "The value of emotional intelligence for high performance coaching". International Journal of Sports Science and Coaching, 6(3): 315-328.

Chelladurai, P., 2006, Management of human resources in sport and recreation (3rd ed.). Champaign, IL: Human Kinetics.

Cordery, C. J., D. Sim and R. F. Baskerville, 2013, “Three models, one goal: Assessing financial vulnerability in New Zealand amateur sports clubs". Sport Management Review, 16(2): 186199.

Costarelli, V. and D. Stamou, 2009, "Emotional intelligence, body image and disordered eating attitudes in combat sport athletes". Journal of Exercise Science \& Fitness, 7(2): 104-111.

Crombie, D., C. Lombard and T. Noakes, 2009, "Emotional intelligence scores predict team performance in national cricket competition". International Journal of Sports Science and Coaching, 4(2): 209-224.

Cunningham, G. B., 2008, "Creating and sustaining gender diversity in sport organizations". Sex Roles, 58: 136-145.

Ekkekakis, P., 2013, The measurement of affect, mood, and emotion: A guide for health-behavioral research. New York: Cambridge University Press.

Engelberg, T., D. H. Zakus, J. L. Skinner and A. Campell, 2012, "Defining and measuring dimensionality and targets of the commitment of sport volunteers". Journal of Sport Management, 26(2): 192-205.

Erturan-Ogut, E. E. and M. Y. Sahin, 2014, "Political clientelism in Turkish sports federations". European Sport Management Quarterly, 14(5): 556-566.

Erturan, E. E. and A. F. Imamoglu, 2011, "Comparative analysis of sport clubs in Germany and Turkey: A new approach to structure and function of the sport clubs in Turkey". Hacettepe Journal of Sport Sciences, 22(2): 54-68.

Fernández-Berrocal, P., R. Cabello and R. Castillo, 2012, "Gender differences in emotional intelligence: The mediating effect of age". Behavioral Psychology/Psicologia Conductual, 20(1): 77-89.

Firth, R., 1930, "A dart match in Tikopia”. Oceania, 1(1): 64-96.

Gardner, H., 2011, Frame of mind: The theory of multiple intelligences (10th ed.). New York: Basic Books.

George, J. M., 2000, "Emotions and leadership: The role of emotional intelligence". Human Relations, 53(8): 1027-1055.

Goleman, D., 1995, Emotional intelligence: Why it can matter more than IQ. New York: Bantam Books.

Goleman, D., 1998, "What makes a leader?”. Harvard Business Review, 76(6): 93-102.

Harrison, Y. D. and V. Murray, 2012, "Perspectives on the leadership of chairs of nonprofit organization boards of directors: A grounded theory mixed-method study". Nonprofit Management \& Leadership, 22(4): 411-437.

Hoye, R., 2006, "Leadership within Australian voluntary sport organization boards". Nonprofit Management and Leadership, 16(3): 297-313. 
Özdinç, Ö., Bilir, P., \& Özdinç, Y. (2017). Exploring the emotional intelligence of leaders in governance of non-profit sports organizations: A voluntary vs. non-voluntary comparison. Journal of Human Sciences, 14(4), 4464-4479. doi:10.14687/jhs.v14i4.4839

Hoye, R., 2007, “Commitment, involvement and performance of voluntary sport organization board members". European Sport Management Quarterly, 7(1): 109-121.

Hwang, S., D. L. Feltz and J. Lee, 2013, "Emotional intelligence in coaching: Mediation effect of coaching efficacy on the relationship between emotional intelligence and leadership style". International Journal of Sport and Exercise Psychology, 11(3): 292-306.

Johnson, W., 1949, "A study of emotion revealed in two types of athletic sports contests". Research Quarterly, 20(1): 72-79.

Kafetsios, K., 2004, "Attachment and emotional intelligence abilities across the life course". Personality and Individual Differences, 37(1): 129-145.

Khoo, S., and R. Engelhorn, 2011, "Volunteer motivations at a national Special Olympics event". Adapted Physical Activity Quarterly, 28(1): 27-39.

Kolar, D., S. Skilton and L. W. Judge, 2016, "Human resource management with a volunteer workforce". Journal of Facility Planning, Design and Management, 4(1): 5-12.

Kristianasen, W., 2015, “Turkey's not so splendid isolation”. Le Monde Diplomatique. Retrieved from http://mondediplo.com/2015/01/02turkey on 04 May 2017.

Laborde, S., A. Brull, J. Weber and L. S. Anders, 2011, "Trait emotional intelligence in sports: A protective role against stress through heart rate variability?". Personal and Individual Differences, 51(1): 23-27.

Laborde, S., F. Dosseville, F. Guillen and E. Chaves, 2014, "Validity of the trait emotional intelligence questionnaire in sports and its links with performance satisfaction". Psychology of Sport and Exercise, 15(5): 481-490.

Laborde, S., F. Lautenbach, M. S. Allen, C. Herbert and S. Achtzehn, 2014, "The role of trait emotional intelligence in emotion regulation and performance under pressure". Personality and Individual Differences, 57: 43-47.

Landy, F. J., 2006, "The long, frustrating, and fruitless search for social intelligence: A cautionary tale". In Murphy K. R. (ed.), A critique of emotional intelligence. New Jersey: Lawrence Erlbaum, pp. 81-124.

Lane, A. M., T. J. Devonport, I. Soos, I. Karsai, E. Leibinger and P. Hamar, 2010, "Emotional intelligence and emotions associated with optimal and dysfunctional athletic performance". Journal of Sports Science and Medicine, 9(3): 388-392.

Lane, A. M., B. B. Meyer, T. J. Devonport, K. A. Davies, R. Thelwell, G. S. Gill, G. D. P. Diehl, M. Wilson and N. Weston, 2009, "Validity of the emotional intelligence scale for use in sport". Journal of Sports Science and Medicine, 8(2): 289-295.

Lane, A. M., R. Thelwell and T. J. Devonport, 2009, "Emotional intelligence and mood states associated with optimal performance". Sensoria: A Journal of Mind, Brain, and Culture, 5(1): 67-73.

Lane, A. M., R. Thelwell, J. Lowther and T. J. Devonport, 2009, "Emotional intelligence and psychological skills use among athletes". Social Behavior and Personality: An International Journal, 37(2): 195-201.

Lane, A. M. and M. Wilson, 2011, "Emotions and trait emotional intelligence among ultraendurance runners". Journal of Science and Medicine in Sport, 14(4): 358-362.

Lasby, D. and J. Sperling, 2007, "Understanding the capacity of Ontario sports and recreation organizations". Retrieved from http://sectorsource.ca/sites/default/files/resources/files/s-r ontario.pdf on 04 May 2017.

Lozovina, M., D. Bonacin and V. Lozovina, 2012, "Emotional intelligence and determination of sociometric status in sport". Sport Science, 5(2): 66-74.

Lu, J., 2016, “The philanthropic consequence of government grants to nonprofit organizations". Nonprofit Management and Leadership, 26(4): 381-400. 
Özdinç, Ö., Bilir, P., \& Özdinç, Y. (2017). Exploring the emotional intelligence of leaders in governance of non-profit sports organizations: A voluntary vs. non-voluntary comparison. Journal of Human Sciences, 14(4), 4464-4479. doi:10.14687/jhs.v14i4.4839

Lu, F. J., G. S. Li, E. Y. Hsu and L. Williams, 2010, "Relationship between athletes' emotional intelligence and precompetitive anxiety". Perception and Motor Skills, 110(1): 323-338.

Magnusen, M. and P. L. Perrewé, 2016, "The role of social effectiveness in leadership: A critical review and lessons for sport management". Sport Management Education Journal, 10(1): 6477.

Magyar, T. M., M. R. Guivernau, L. A. Gano-Overway, M. Newton, M. S. Kim, D. L. Watson and M. D. Fry, 2007, "The influence of leader efficacy and emotional intelligence on personal caring in physical activity". Journal of Teaching in Physical Education, 26: 310-319.

Maier, F., M. Meyer and M. Steinbereithner, 2016, "Nonprofit organizations becoming businesslike: A systematic review". Nonprofit and Voluntary Sector Quarterly, 45(1): 64-86.

Mayer, J. D., D. R. Caruso and P. Salovey, 1999, "Emotional intelligence meets traditional standards for an intelligence". Intelligence, 27(4): 267-298.

McCann, S., 1999, "The secret of athletic excellence". Olympic Coach, 9: 8-9.

Meyer, B. B. and T. B. Fletcher, 2007, "Emotional intelligence: A theoretical overview and implications for research and professional practice in sport psychology". Journal of Applied Sport Psychology, 19(1): 1-15.

Meyer, B. B. and S. Zizzi, 2007, "Emotional intelligence in sport: Conceptual, methodological, and applied issues". In Lane A. M. (ed.), Mood and human performance: Conceptual, measurement and applied issues. Hauppauge, New York: Nova Science Publishers, pp. 131-154.

Ministry, 2014, "Ministry of Youth and Sport". Retrieved from http://www.gsb.gov.tr/Sayfalar/2236/10/Tarihce on 04 May 2017.

Petrides, K. V. and A. Furnham, 2000, "On the dimensional structure of emotional intelligence". Personality and Individual Differences, 29(2): 313-320.

Petrides, K. V. and A. Furnham, 2006, "The role of trait emotional intelligence in a genderspecific model of organizational variables". Journal of Applied Social Psychology, 36(2): 552569.

Puig, N. and A. Villanova, 2011, "Positive functions of emotions in achievement sports". Research Quarterly for Exercise and Sport, 82(2): 334-344.

Riot, C., G. Cuskelly, D. Zakus and C. J. Auld, 2008, "Volunteers in sport: Issues and innovation-A report prepared for NSW Sport and Recreation". Retrieved from http://dsr.nsw.gov.au/assets/pubs/industry/study_volunteers-in-sport.pdf on 21 April 2017.

Ruffman, T., J. D. Henry, V. Livingstone and L. H. Phillips, 2008, "A meta-analytic review of differences in emotion recognition between younger and older adults". Neuroscience and Biobehavioral Reviews, 32: 863-881.

Sahin, M. Y. and A. F. Imamoglu, 2011, "Views of parliamentarians and academics on the interaction of politics and sports". Gazi Beden Egitimi ve Spor Bilimleri Dergisi, 16(2): 1-21.

Salovey, P. and J. D. Mayer, 1990, "Emotional intelligence". Imagination, Cognition and Personality, 9(3): 185-211.

Sandler, C., 2014, "Developing female leaders: Helping women reach the top". Industrial and Commercial Training, 46(2): 61-67.

Schlesinger, T., B. Egli and S. Nagel, 2013, "Continue or terminate? Determinants of long-term volunteering in sports clubs". European Sport Management Quarterly, 13(1): 32-53.

Schneider, R. C., 2012, “Emotional intelligence: The overlooked component of sport leadership". International Journal of Sport and Society, 3(3): 43-56.

Schutte, N. S., J. M. Malouff, L. E. Hall, D. J. Haggerty, J. T. Cooper, C. J. Golden and L. Dornheim, 1998, "Development and validation of a measure of emotional intelligence". Personality and Individual Differences, 25(2): 167-177.

Shilbury, D., 2015, “Strategic leadership through strategic planning”. In O’Boyle I., D. Murray, and P. Cummins (eds.), Leadership in sport. New York: Routledge, pp. 107-120. 
Özdinç, Ö., Bilir, P., \& Özdinç, Y. (2017). Exploring the emotional intelligence of leaders in governance of non-profit sports organizations: A voluntary vs. non-voluntary comparison. Journal of Human Sciences, 14(4), 4464-4479. doi:10.14687/jhs.v14i4.4839

Shilbury, D. and L. Ferkins, 2011, "Professionalisation, sport governance and strategic capability". Managing Leisure, 16(2): 108-127.

Simmons, J. E., 1959, "Prevention and treatment of undue emotional aspects of athletic competition". The Journal of the Indiana State Medical Association, 52: 1763-1765.

Singer, M. I. and J. A. Yankey, 1991, "Organizational metamorphosis: A study of eighteen nonprofit mergers, acquisitions, and consolidations". Management and Leadership, 1(4): 357-369.

Solanki, D. and A. M. Lane, 2010, "Relationships between exercise as a mood regulation strategy and trait emotional intelligence". Asian Journal of Sports Medicine, 1(4): 195-200.

Spanish Ministry of Education, Culture, and Sport, 2014, "Functions and powers". Retrieved from http://www.mecd.gob.es/ministerio-mecd/en/organizacion/funciones-y-competencias.html on 21 April 2017.

Sport New Zealand, 2015a, “Governance benchmarking review 2014”. Retrieved from http://www.sportnz.org.nz/assets/Uploads/attachments/managing-sport/strongorganisations/Governance-Benchmarking-Summary-May-2014.pdf on 04 May 2017.

Sport New Zealand, 2015b, "The role of the board chair". Retrieved from http://www.sportnz.org.nz/assets/Uploads/attachments/managing-sport/strongorganisations/The-Role-of-the-Board-Chair.pdf on 04 May 2017.

Stough, C., M. Clements, L. Wallish and L. Downey, 2009, "Emotional intelligence in sport: Theoretical linkages and preliminary empirical relationships from basketball". In Parker J. D., D. H. Saklofske and C. Stough (eds.), Assessing emotional intelligence: Theory, research, and applications. New York: Springer, pp. 291-305.

Thelwell, R. C., A. M. Lane, N. J. Weston and I. A. Greenlees, 2008, "Examining relationships between emotional intelligence and coaching efficacy". International Journal of Sport and Exercise Psychology, 6(2): 224-235.

Voight, M., 2014, The sports leadership playbook: Principles and techniques for coaches and captains. North Carolina: McFarland \& Company.

Vos, S., D. Breesch, S. Kesenne, W. Lagae, J. van Hoecke, B. Vanreusel and J. Scheerder, 2012, “The value of human resources in non-public sports providers: The importance of volunteers in non-profit sports clubs versus professionals in for-profit fitness and health clubs". International Journal of Sport Management and Marketing, 11(1/2): 4-25.

Wagstaff, C. R., S. Hanton and D. Fletcher, 2013, "Developing emotion abilities and regulation strategies in a sport organization: An action research intervention". Psychology of Sport and Exercise, 14(4): 476-487.

Wicker, P. and C. Breuer, 2011, "Scarcity of resources in German non-profit sport clubs". Sport Management Review, 14(2): 188-201.

Wicker, P. and C. Breuer, 2013, "Understanding the importance of organizational resources to explain organizational problems: Evidence from nonprofit sport clubs in Germany". Voluntas, 24(2): 461-484.

Wicker, P., C. Breuer and B. Hennigs, 2012, "Understanding the interactions among revenue categories using elasticity measures-evidence from a longitudinal sample of non-profit sport clubs in Germany". Sport Management Review, 15(3): 318-329.

Wicker, P., C. Breuer and T. von Hanau, 2012, "Gender effects on organizational problems-evidence from non-profit sports clubs in Germany". Sex Roles, 66:105-116.

Wolff, S. B., 2005, "Emotional Competence Inventory (ECI): Technical manual". Retrieved from http://www.eiconsortium.org/pdf/ECI 2 0 Technical Manual_v2.pdf on 04 May 2017.

Wong, C. S. and K. S. Law, 2002, "The effects of leader and follower emotional intelligence on performance and attitude". The Leadership Quarterly, 13(3): 243-274.

Zizzi, S. and H. H. Deaner, 2003, "The relationship between emotional intelligence and performance among college basketball players". Journal of Applied Sport Psychology, 15(3): 262-269. 
Özdinç, Ö., Bilir, P., \& Özdinç, Y. (2017). Exploring the emotional intelligence of leaders in governance of non-profit sports organizations: A voluntary vs. non-voluntary comparison. Journal of Human Sciences, 14(4), 4464-4479. doi:10.14687/jhs.v14i4.4839

\section{Appendices}

\section{Appendix A: \\ Computations for Power}

1. Size Estimations. We used the GPower 3.1 software to compute the effect size estimation. We computed the squared population multiple correlation coefficient $\left(\varrho^{2}\right)$ between the dependent EI score $(\mathrm{y})$ and the independent factors of age $\left(\mathrm{x}_{1}\right)$ and sporting experience $\left(\mathrm{x}_{2}\right)$. For this computation, we input the outcome values of the pilot study, which were $r(24)=.581, p<$ .01 and $r(24)=.218, p=.29$ for $\mathrm{x}_{1}$ and $\mathrm{x}_{2}$, respectively (see Pilot Study for details). The alternate $\varrho^{2}$ from this input returned $\mathrm{H}_{1} \varrho^{2}=.385$. Further one-tail calculations based on this input parameter with $a=.05$ yielded the critical $R^{2}=.187$ and that 32 participants (per group) would be sufficient to achieve power of .95. A screenshot of the analysis is given in figure A1.

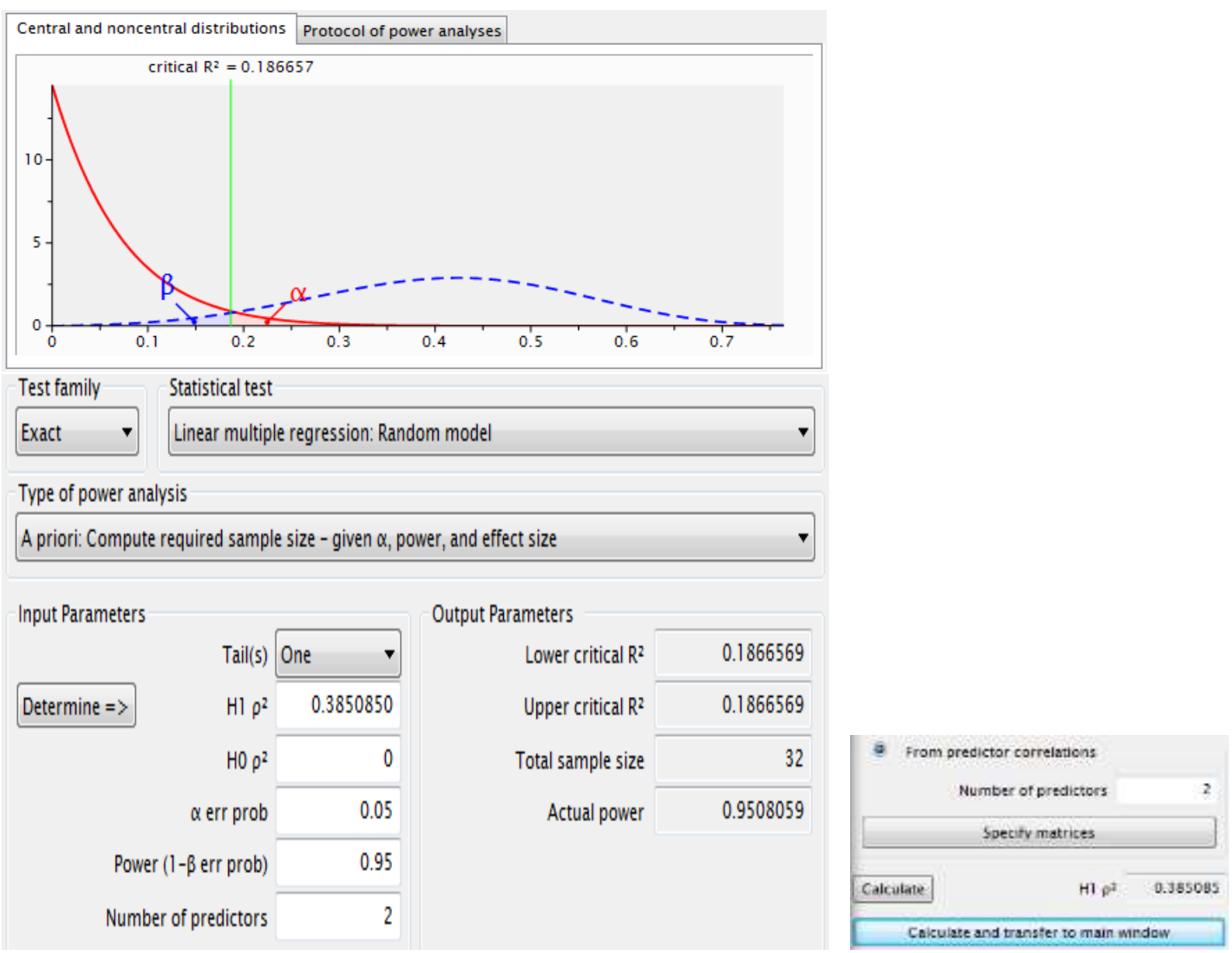

Figure A1. A priori computations of power and size estimations on GPower 3.1 
Özdinç, Ö., Bilir, P., \& Özdinç, Y. (2017). Exploring the emotional intelligence of leaders in governance of non-profit sports organizations: A voluntary vs. non-voluntary comparison. Journal of Human Sciences, 14(4), 4464-4479. doi:10.14687/ihs.v14i4.4839

\section{Appendix A (continues)}

2. Post hoc Power. Using the same software we computed the post hoc power. We entered into the software the following figures that we achieved in the multiple regression: confidence level $(1-a)=.436$, where $a=.564$, total sample size $(\mathrm{n})=87$, and observed $R^{2}=.130$ (see footnote 'c' to table 3). For two predictors, the output revealed an achieved power of .85. A screenshot of the analysis is given in figure A2.
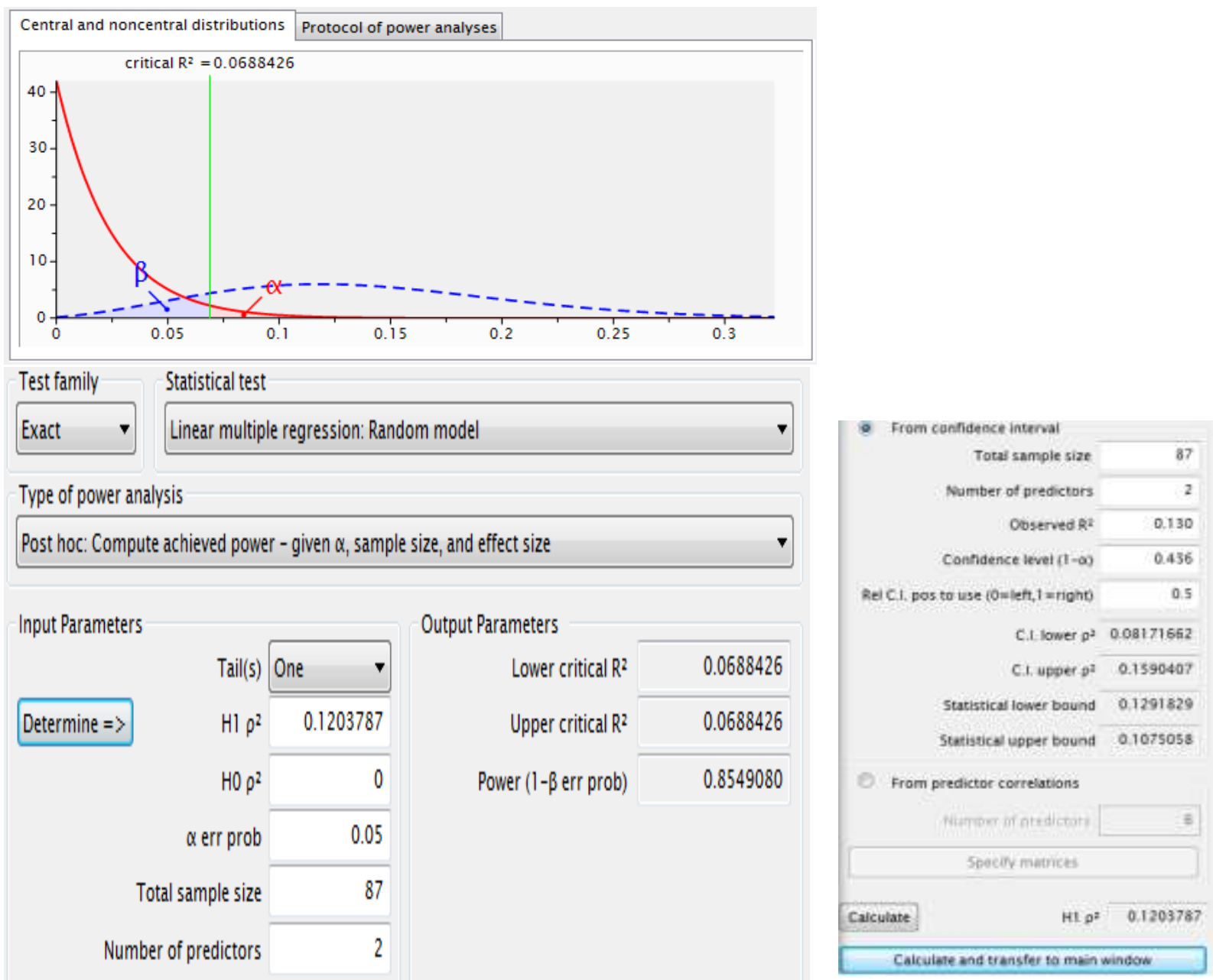

Figure A2. Post hoc power computation on GPower 3.1 

sports organizations: A voluntary vs. non-voluntary comparison. Journal of Human Sciences, 14(4), 4464-4479. doi:10.14687/jhs.v14i4.4839

\section{Appendix B:}

Normality Checks for the EI Scores

\section{Normal Q-Q Plot of SREIS scores}

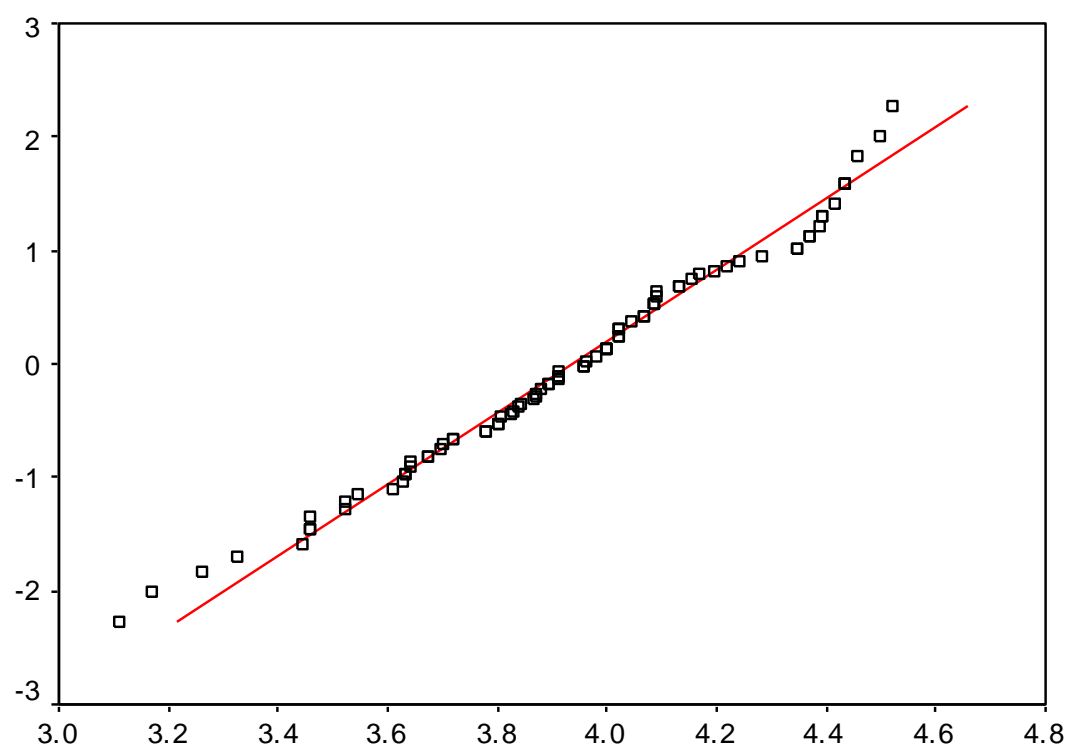

Observed Value

Notes:

$M=3.94, S E=.03$, Median $=3.96$, Mode $=4.00$, Skewness $=-.27$, Kurtosis $=-.17, \mathrm{KS}=$ $.064, d f=87, p=.196$.

Poles on the SREIS: 1 = Strongly disagree, $5=$ Strongly agree 